\title{
Architectural Styles of Malaysian Mosque: Suitability In Compact Urban Settings
}

\author{
Nayeem Asif ${ }^{1, *}$, Nangkula Utaberta $^{1}$ and Arman Sarram ${ }^{1}$
}

${ }^{1}$ Universiti Putra Malaysia

\begin{abstract}
The concept of urban mosque stems from more extensive reasons that mostly come from the overall issues of industrialization. Considering the challenges related to rapid urban growth, public institutions, such as mosque and its compatibility is required to be assessed in the context of compact cities. This study, therefore, aims to evaluate the planning and layout of six different styles of mosque in Malaysia regarding their suitability in compact urban settings. Due to its genre, the study adopts a case study as a qualitative research strategy as its research method. Content analysis is conducted on the compiled literature to indicate the expected outcome. Following a brief comparative discussion, this paper shows that mosque with modern architectural style among all six typologies is most suitable in the context of compact urban settings. Factors considered for the evaluation of mosques include layout progression of the mosque whether horizontal or vertical, provision for vertical stacking of spaces, symmetry in topology as well as in elevation and space types regarding flexible usage. The scope of this paper is limited to the assessment of literature only, which opens the window for a further in-depth study of actual case studies related to this topic.
\end{abstract}

\section{Introduction}

Mosque acts as the most significant institution for the Muslims as a nucleus of a globally united community. The practice was initiated by Prophet Muhammad (PBUH) when he established the mosque in Madinah as the center of promoting and spreading Islam or the newly formed Muslim community. Soon after its establishment, the mosque becomes a very strong institution that no other institution in the world can reach its purity, sanctity, and charm. Mosque is the place where the believers contemplate and worship Allah; it is a place for self-reflection and prayer [1]

Over the years of transformation that Muslim society underwent, mosques have also taken many roles apart from its main spiritual function. "From rudimentary roles, it evolved into a complex and institutional one" [2]. Islamic society which adheres to Islamic principles as the primary guide for most of its activities from spiritual, economic to political has compelled the mosque's functions to overlap to accommodate basic and essential facets of life for Muslims. [3] Ali Delavar (2012) also stated that mosque architecture plays an important role in religion and culture in the people's knowledge and establishes unity among Muslims because it provides a venue for communication between the mosque and the world [4]. Furthermore, the role of a mosque as an institution is highly important especially in Muslim majority population because it supports in solving social problems and develop a more integrated community[5]

Modern society issues are varied and complex; urban communities most especially are challenged with increasing issues of physical, social, economic and even moral nature due to the rising level of urbanization and population growth. It creates the need for assessing urban institutions such as mosques to be evaluated in light of the contemporary context. This study, therefore, attempts to assess the suitability of different types of mosque design within contemporary cities in the context of Malaysia.

\section{The concept of mosque}

From a linguistic perspective, the word Masjid refers to a place of prostration. Its root is derived from ' $s a-j a-d a$,' which means prostration. Prostration is a part of the prayer for Muslims in which a person's forehead touches the ground. It is a pose that symbolizes complete submission of a believer to Allah. Prophet (PBUH), said, "The (whole) earth has been made a mosque and a means of purification for me, so wherever a man of my Ummah maybe when the time for prayer comes, let him pray.'"[6]

The English word for Masjid is a mosque[7]. However, the word Masjid has multi-layered meaning while the word mosque refers to only a certain typology of a religious building. The English word mosque is derived from a French word which now is used widely to

* Corresponding author: author@e-mail.org 
refer to the religious intuition of Muslims around the world. The word mosque extracts from the word "masjid." Briefly, "sajd" means prostrate that indicates the act of prostration or "sujud" which is one of the symbols of the ritual activities in Islam. The English version 'mosque' was also extracted from the French word "mosque'e" or Spanish word "Mezquita." Mosque is regarded as a site for worshiping that in this place Muslims devote themselves to God [8].

Therefore, the term mosque in its essence represents the institution which is the house of Allah and a place where the believers' prostate to Allah as a declaration of their faith. Here the Muslims pray shoulder to shoulder, united to fulfill their religious obligation with the desire to please Allah.

\subsection{Mosques in Malaysia}

Malaysia as Muslim majority nation has a diverse cultural and architectural style of mosque all over its country. It reflects the influences of different cultures both internally and externally, blending elements exclusive to the area of its location whether it is in the east or west of Malaysia, the available materials and prevailing architectural design of the era. Malaysia has various mosques in the country and has adopted different architectural designs inspired by varying ethnicity and cultures, different colonialism periods, foreign influence, technological advancements and the political influences [9]

Earliest typological design of mosque in Malaysia is believed to be purely made from timber with the usual characteristic of the pyramidal roof of two tiers with long gable house type. Introduction of masonry later on allowed further expansion into three tiers [10]. It was also described to be similar to Malay houses which were raised on slits and materials of thatch and clay were used for tiles, a distinctly regional approach attributed to the environment and climate [11]. When it came to ornamentation, a classic Malay Masjid would be ornamented with at least twenty carved components which can be subdivided into the structure, element, and decoration. These were prominent in the façade, doors, wind channels on top of the doors or windows and wall panels [12]

Although many influences can be attributed to the architectural design of Mosques in Malaysia, much of its background can be traced through the country's historical events which significantly brought over the changes in Malaysian mosques. In the early 15th century merchants from various parts of the world were attracted by the rich trading in the Malacca State, this included Muslims businessmen from the Middle East, Indian subcontinent, and Indonesia. The settlement of these people resulted in the creation of mosque and qur'anic schools called madrasahs in their community. Such examples are the Muslim Achenese community in Penang while other settlements of Indian, Pakistani, Javanese and Arab of origin can also be found all over the country. These settlements showed distinctive styles in their mosques [12].
Also, the colonial period during the Portuguese, Dutch and British have also extensively influenced architectural styles because they carried with them the new cultural and technological ideas which influenced the construction and presentation of structures. A good example of this influence would be the British colonial period wherein the wave of Indians immigrants was at its peak and similarly have transported another style into the fold. An example of this influence is the Kampung Hulu and Kampung Kling mosques which were built during the 1700 s by Muslim Indian merchants. The design showcases a combination of Melaka Malay, Chinese, Hindu and Sumatran influences [11].

Moreover, British colonial architecture in Malaysia also inspired an eclectic design which included mainly Moorish inspired, Tudor, Neo-classical and Neo-Gothic. Mosques and other buildings that were made by British architects who adopted the architectural languages of British India as well as other British colonies around the world. They were influenced by the Moghul architecture that was incorporated into various structures in Malaysia. This was possibly a dominant theme because of the Islamic background of most of its inhabitants the Malays specifically Sultans and other community leaders [11]. After gaining its independence, Kuala Lumpur and other major cities in the peninsular area embarked into rapid industrialization especially in the 1970s and 1980s [13]. which also saw significant changes in the built environmental landscape, more structures were made such as mosques to accommodate the needs of its population. Considering the limited size of Kuala Lumpur and other cities of the Klang Valley area, compact city principles are in place and usually central to every community is a mosque to serve the people.

\section{Methodology}

This study is conducted qualitatively from the secondary data source. Data is compiled through an extensive literature review on the subject matter followed by descriptive analysis to compare the different styles of mosques in Malaysia and their suitability in compact urban settings. The brief recommendation is given based on the analysis which is recorded at the end of this paper.

\section{Architectural styles of Mosques in Malaysia}

According to [14] Ghafar (1999) Ahmad's work regarding architectural styles of Malaysia, there is three classification of a mosque in Malaysia which is according to the relative period which follows (1) Vernacular Mosque, (2) Colonial Mosque and (3) Modern Mosque [11]

While Tajuddin and Utaberta proposed a classification of seven styles for the architectural language of a mosque in the Malay Archipelago. They are the Traditional Vernacular, the Sino-Eclectic, the Colonial, the North Indian, the Modern Vernacular, the Modernistic Expressionism, the Post-Modern Revivalism [15]. 


\subsection{Vernacular Mosque}

According to [11], a mosque in this category specifically considers the inherent aspects of Malaysia which are weather, materials and other native conditions. Vernacular mosques show aspects native to Malaysia which consider the four major factors in its architectural style: climate, locally founded building materials, existing craftsmanship, and sub-cultural background.

This is dated from the 18th century to present and would usually refer to old Malay dwellings that were responsive to the tropical weather. This is shown through pitched roofs that allowed rainwater to drain off smoothly, stilts to elevate the mosque above ground level in case of floods, multiple openings such as windows, fanlights and carving for allowing crossventilation. Furthermore, building materials native to Malaysia such as timber, bamboo, stone, clay, and thatch are extensively used as it is widely available. It is characterized with highly efficient craftsmanship as exemplified in its windows, fanlights, carving wall panels, fascia boards and well-designed "mimbar" with complex floral motifs. There are two different types of architectural styles for the vernacular mosque which are: (1) Traditional and (2) Regional. Traditional mosque typically show inspiration from traditional Malay culture, while regional vernacular mosques have a mixed of regional influence such as the two or three-tiered rood with decorative rood ridges and clay tiles, square-shaped buildings and octagonal minarets. This style can also be seen in early mosques built in parts of Indonesia[16] Kampung Laut Mosque, Nilam Puri, Kelantan (the 1730's), Langgar Mosque, Kota Bharu, Kelantan (1871), Paloh Mosque, Ipoh, Perak (1912) and Kampung Raja Mosque, Seremban, Negeri Sembilan (1924) display the styles and characteristics of the vernacular mosque with a traditional influence. While regional influence in vernacular style can be found in Tengkera Mosque, Malacca (1728), Kampung Keling Mosque, Malacca (1748), Old Mosque of Kampung Masjid Tinggi, Bagan Serai, Perak (1929) and Tanjung Keling Mosque, Malacca (1930).

\subsection{Sino-Eclectic Style}

Sino-eclectic depicts two terms bonded together to refer to a particular style. Sino relates to Chinese impact, and Eclectic signifies a blend of at least two impacts of architectural influences. Under this term Sino-eclectic, two distinct but related styles can be found. The first type is the three-tiered pyramidal rooftop shape and the second type is the two-tiered level pyramidal rooftop. Apart from the difference in the rooftop, these two substyles seems to be similar in most other contexts. The first type is characterized primarily by its distinctive three-layered pyramidal roof form similar to that of the conventional vernacular style.

The primary difference between these styles is denoted in the curvature of the rooftop edges which is made of cement. The mosques of this style are, for example, the Kampung Hulu Mosque, the Tengkera Mosque and the Kampung Keling Mosque which are all in Melaka. There is additionally the Undang Kamat Mosque and a couple of others like it situated at different spots in Negeri Sembilan. The Lebuh Acheh Mosque in Penang is another example of this style. The mosque of this style does not have elevated ground floor like vernacular Malay house. They all have slabs on the ground which are raised about a half of a meter with stone stairways getting to the ground floor. The arrangement of the mosque comprises of the prayer area and the Serambi or verandah encompassing either three sections of the square arrangement or surrounding it. These mosques are altogether situated in the thick urban regions, and the building is encompassed by a brick fence with some of the time a roofed entryway like relatively reminiscent of Chinese temples.

\subsection{Colonial Mosque}

Colonial mosques were typically built during the British colonial period in Malaysia which dates between 1795 to 1957. These mosques were both designed by local and British architects. According to [14] Ghafar (1999), the colonial mosque was distinct from vernacular in several ways such as scale and proportion, form, feature, and building materials. Many of them are very much influenced by foreign architecture domes of onion, classical pillars, pointed arches, pilasters, keystones, turrets and pediments and plastered renderings on cornices. It is also a combination of Moorish and classical styles that display an Islamic image.

\subsection{European Classical Style}

Classical European style alludes to the High Renaissance design that came from the Greco-Roman legacy. The key features of this style are the base plan which is divided into three parts and top with a double column supporting semicircular arches or dividers with pilasters. Symmetrical structure of the massing and space is likewise a distinguishing feature. The Sultan Abu Bakar Mosque in Johor Bahru is furnished with four minarets and small dome structures on top. The main prayer space has a hipped rooftop.

The Classical European type is recognized through its intricate cornice details shaping a running band around the building. Windows are additionally surrounded by cornices. Masjid Pasir Pelangi utilizes a profound pyramidal rooftop frame reminiscent of the early vernacular mosques however with no partitioning levels. The minaret is overwhelming in extent and topped by a little pyramid rooftop. Masjid Sultan Ibrahim in Muar, Johor utilizes a hipped rooftop which covers a large central portion of the prayer space. This part of the mosque extends above the remaining roofed area to form clerestory windows which reflect the design of early churches built in Rome.

\subsection{North Indian Style}

This style depicts imitation of Moghul design that once prospered in the Malay Archipelago. The North 
Indian style can be effectively recognized from any other styles because of its signature onion domes, a large number of spires and domed shades, multiple minarets, horseshoe or multi-foil curves on a column with decoration. Masjid Ubudiah in Perak, the Masjid Kapitan Keling in Penang, the Masjid Jame' and Masjid India in Kuala Lumpur are prime examples of North Indian style. The designs of the mosques of this particular style have some resemblance with other styles with its domed space and arched corridors. The mosque premise is usually fenced and surrounded by typical green lawns.

\subsection{Modern Mosque}

Modern mosque, on the other hand, is those built during the period after Malaysian independence from colonial rule, from 1958 onwards. Many modern designs were shown in the architectural style of Malaysia, and this was in parallel with the technological and structural advancements of the times. These are usually characterized by larger scales to accommodate the increasing population, use of modern materials such as concrete, bricks, steel, and marble. Design-wise although modern mosque adheres to modern principles of architecture it still retained many former designs which are distinctive of mosque traditional architecture in a sense where common features such as domes, tall minarets, and high ceilings are prevalent. Other distinctive features are the infusion of the well-designed landscape such as plants, water features patterned pavements, garden lighting, and signage.

There are two types of this style, the modern style incorporating technological advancement of that time as well as the available craftsmanship. Such examples are the National mosque of Kuala Lumpur. This is considered advancements because of its large scale it has which apart from its large structural proportion, it can accommodate many people at once for prayer. Additionally, it also has expanded functional rooms for other purposes such as education, office, guests rooms, Imam's room, and storerooms. Another classification of a modern mosque which combines various Islamic influences from around the world into the architectural style of the Mosque. Countries such as Turkey, the Middle East, and Northern Africa. This is usually characterized by design and colour, having high minarets and a surrounding well-kept landscape [11].

\subsection{Post Modern Revivalism}

Postmodern indicates the approach that negates the standards and orders of that which was comprehended as the modern style. Revivalism indicates one of the numerous ways which the postmodern designers attempt to redefine the meaning of architecture for the overall population as opposed to for the selected few. Foreign Revivalism and Vernacular Revivalism are the two sorts of Post-Modernist Revivalism that can be classified. Foreign Revivalism in mosque design is by all accounts the demand of the day with cases such as the Masjid Putra, Masjid Shah Alam, the Masjid Wilayah, the UTM Mosque in Johor, the Sarawak State Mosque and many others. These luxurious endeavours of alleged 'Islamic Glory' is the favoured dialect by those in power to express their 'deep concern' for the imperative image of Islam.

The utilization of a diverse exhibit of Turkish and Iranian dome structures, Turkish and Egyptian minarets, Persian Iwan passages, luxurious yards encompassed by the Sahn, and an Arabian hypo-style arranging creation and pointed or half-circle arches washed in lavish traditional 'Islamic' embellishments are the signature of mosque architecture. Vernacular Revivalism shows a humbler approach with its three-layered pyramidal rooftop. The Melaka State Mosque speaks to the grandiose extreme while Jimmy Lim's ASPA mosque for the towns of Pahang speaks to the more humbler adaptation. The Melaka State Mosque illustrates the use of arches and entryways with its Neo-vernacular symbolism while the ASPA mosque provides a sensible version of contemporary timber buildings without the kind of any Arab or Indian influence. Except for the ASPA mosque, the others have boundary defined with walls and inside is equipped with water features, cleared grounds and grass gardens with the much sculptural organization. Locations of these mosques are over the most astounding areas, amidst artificial lakes or isolated from the urban fabric.

\section{Results and discussion}

This section presents a brief discussion comparing the above stated architectural styles. It is to be noted that the discussion focuses on the layout and planning characteristics of the mosques. Ornamental aspects and formal expression are omitted considering the scope of this study[17]. Pointed out several aspects regarding mosque design in urban settings which affect the functional efficiency of the mosque, i.e. layout progression and land use, vertical stacking of functions and presence of single-use space versus multifunctional space. Concerning the focus of this study, the design of the mosque of the above-stated styles analyzed from the perspective of layout progression, vertical stacking of function and space types. Refer to Table.1 to see comparative discussion on mosque style in Malaysia. 
Table 1. Comparative discussion on mosque style in Malaysia.

\begin{tabular}{|c|c|c|c|c|c|}
\hline Style & Example & $\begin{array}{l}\text { Layout } \\
\text { progression }\end{array}$ & $\begin{array}{l}\text { Vertical } \\
\text { stacking of } \\
\text { function }\end{array}$ & Space type & Remarks \\
\hline $\begin{array}{l}\text { Vernacular } \\
\text { Mosque }\end{array}$ & $\begin{array}{l}\text { Masjid } \\
\text { Kampung } \\
\text { Laut, } \\
\text { Kelantan }\end{array}$ & $\begin{array}{l}\text { Horizontal layout } \\
\text { with main prayer } \\
\text { hall on the } \\
\text { elevated ground } \\
\text { floor surrounded } \\
\text { by a balcony }\end{array}$ & $\begin{array}{l}\text { Single storied } \\
\text { mosque } \\
\text { building }\end{array}$ & Single-use monospace & $\begin{array}{l}\text { This style is not } \\
\text { favorable for a mosque } \\
\text { in compact cities }\end{array}$ \\
\hline $\begin{array}{l}\text { Sino- } \\
\text { Eclectic } \\
\text { Style }\end{array}$ & $\begin{array}{l}\text { Kampung } \\
\text { Hulu } \\
\text { Mosque, } \\
\text { Malacca }\end{array}$ & $\begin{array}{l}\text { Resembles } \\
\text { similar } \\
\text { characteristics as } \\
\text { above except the } \\
\text { ground floor is } \\
\text { not elevated }\end{array}$ & $\begin{array}{l}\text { Single storied } \\
\text { mosque } \\
\text { building }\end{array}$ & Single-use monospace & $\begin{array}{l}\text { This style also is not } \\
\text { favorable for a mosque } \\
\text { in compact cities }\end{array}$ \\
\hline $\begin{array}{c}\text { Colonial } \\
\text { Mosque } \\
20 y+1 \\
\end{array}$ & $\begin{array}{l}\text { Sultan } \\
\text { Abu } \\
\text { Bakar } \\
\text { Mosque, } \\
\text { Johor } \\
\text { Bahru }\end{array}$ & Horizontal layout & $\begin{array}{l}\text { Two storied } \\
\text { mosques with } \\
\text { both floor used } \\
\text { as a prayer hall }\end{array}$ & $\begin{array}{l}\text { One large prayer hall } \\
\text { at center, additional } \\
\text { spaces are arranged } \\
\text { centering the prayer } \\
\text { space. Usually } \\
\text { symmetric design }\end{array}$ & $\begin{array}{l}\text { This style is more } \\
\text { favorable for urban } \\
\text { setting compared to the } \\
\text { first two styles. } \\
\text { However, the style does } \\
\text { not represent the best } \\
\text { scenario }\end{array}$ \\
\hline $\begin{array}{l}\text { European } \\
\text { Classical } \\
\text { Style }\end{array}$ & $\begin{array}{l}\text { Sultan } \\
\text { Ibrahim } \\
\text { Mosque }\end{array}$ & $\begin{array}{l}\text { Similar } \\
\text { resemblance with } \\
\text { the Colonial } \\
\text { mosques }\end{array}$ & $\begin{array}{l}\text { Usually single } \\
\text { storied }\end{array}$ & Single-use monospace & $\begin{array}{l}\text { Less favorable option } \\
\text { than colonial mosques }\end{array}$ \\
\hline 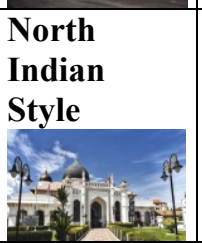 & $\begin{array}{l}\text { Kapitan } \\
\text { Keling } \\
\text { Mosque, } \\
\text { Penang }\end{array}$ & $\begin{array}{l}\text { Not much } \\
\text { different in terms } \\
\text { of the layout } \\
\text { from colonial } \\
\text { style }\end{array}$ & $\begin{array}{l}\text { Usually single } \\
\text { storied }\end{array}$ & Single-use monospace & $\begin{array}{l}\text { Less favorable option } \\
\text { than colonial mosques }\end{array}$ \\
\hline $\begin{array}{l}\text { Modern } \\
\text { Mosque }\end{array}$ & $\begin{array}{l}\text { National } \\
\text { Mosque } \\
\text { of } \\
\text { Malaysia }\end{array}$ & $\begin{array}{l}\text { Horizontal layout } \\
\text { with vertical } \\
\text { spaces wherever } \\
\text { needed }\end{array}$ & $\begin{array}{l}\text { Vertical } \\
\text { stacking of } \\
\text { spaces if } \\
\text { required by the } \\
\text { function }\end{array}$ & $\begin{array}{l}\text { Large prayer hall with } \\
\text { additional spaces } \\
\text { arranged as per } \\
\text { functional } \\
\text { requirement. Usually } \\
\text { asymmetric design }\end{array}$ & $\begin{array}{l}\text { The provision of } \\
\text { vertical stacking of } \\
\text { spaces as per functional } \\
\text { requirement makes this } \\
\text { style most favorable for } \\
\text { compact settings }\end{array}$ \\
\hline $\begin{array}{l}\text { Post } \\
\text { Modern } \\
\text { Revivalism }\end{array}$ & $\begin{array}{l}\text { Malacca } \\
\text { State } \\
\text { Mosque }\end{array}$ & $\begin{array}{l}\text { Tendency } \\
\text { towards } \\
\text { horizontal } \\
\text { progression }\end{array}$ & $\begin{array}{l}\text { Vertical } \\
\text { stacking of } \\
\text { spaces if } \\
\text { required by the } \\
\text { function }\end{array}$ & $\begin{array}{l}\text { Tend to be symmetric } \\
\text { in layout, thus having } \\
\text { single-use monospaces } \\
\text { than modern mosques }\end{array}$ & $\begin{array}{l}\text { Less favorable than a } \\
\text { modern mosque in } \\
\text { compact urban settings. }\end{array}$ \\
\hline
\end{tabular}

The comparison illustrates that, for a compact urban setting, the modern mosques are the most favorable style regarding space usages, layout progression, and functional accommodation. Moreover, this style due to its asymmetric layout creates more flexibility to achieve optimal land use in arranging its functional spaces following the shape and size of available land. The further empirical study is suggested in this regard to quantifying the aspects of modern style to assess its suitability in compact urban settings.

\section{Conclusion}

The results of this paper have provided insights into the evolution of mosque and how it can be further improved to address modern challenges. Modern mosque, among all other typologies, proves to be the most suitable style for adapting the challenges of contemporary cities with its flexible planning and design characteristics. Urban mosques are built and made to 
serve the fundamental purpose of the mosque which is prayer and other religious activities, however, because of the other essential needs of the community it also serves other purposes which demonstrates the flexibility of mosque in serving the community such as social, economic and even political. This shows the relevance of urban mosque where space constraint an-going issue. Furthermore, the examples of mosques both modern and old were able to demonstrate and retain functionality and aesthetic presentation while maximizing its space allotment.

This study is conducted with the aid of FRGS 2017 [Vote no: 9553400], FRGS 2016 [Vote No: 5524799] granted by Ministry of Higher Education, Malaysia (MoHE) and Geran Putra-Inisiatif Putra Siswazah (IPS) [Vote No: 9617600] granted by Universiti Putra Malaysia. Authors also acknowledge the support of WARIS Research Group and Faculty of Design and Architecture (FRSB), Universiti Putra Malaysia.

\section{References}

1. Raeisian, G., \& Badreh, M. (2013). The Role of Mosques in Urban Development. Journal of Civil Engineering and Urbanism, 3(3), 101-103.

2. Omer, S. (2012). Institutional Decentralization in the History of Islamic Cities: The Role of Political and Religious Schism. Retrieved January 18, 2017, from http://medinanet.org/2012/10/institutionaldecentralization-in-the-history-of-islamic-cities-therole-of-political-and-religious-schism/

3. Saniei, M., \& Delavar, A. (2012). Communicational Role of Mosques Architecture. Asian Social Science, $\quad 8(3), \quad$ 137-141. https://doi.org/10.5539/ass.v8n3p137

4. Asif, N., \& Utaberta, N. (2016). Masjid- The Spiritual and Physical Hub for Community Development (First Edit). Kuala Lumpur: WARIS Research Group. Retrieved from https://www.academia.edu/30093777/Masjid_The Spiritual_and_Physical_Hub_for_Community Development

5. Hillenbrand, R. (2004). Islamic Architecture: Form, Function, and Meaning. Columbia University Press. Retrieved from https://books.google.com/books?id=81uo8Vc04gQC \&pgis $=1$

6. Stacey, A. (2009). WHAT IS A MOSQUE? Retrieved January 20, 2017, from https://www.islamreligion.com/articles/2748/whatis-mosque/

7. Bosworth, C. E. (1986). The encyclopedia of Islam (Volume 5). Leiden Boston Brill 1986

8. Najafi, M., \& Shariff, M. K. B. M. (2011). Factors influencing public attachment to mosques in Malaysia. Archnet-IJAR, 5(3), 7-24.

9. Utaberta, N., \& Mohd Rasdi, M. T. (2010). Deskripsi tipologi, klasifikasi dan analisis perancangan Masjid di malaysia. El- Harakah Journal Budaya Islam, 12(2), 85-100
10. Ahmad, A. G. (1999). The Architectural Styles Of Mosques in Malaysia: From Vernacular to Modern Structures. In Proceedings of the Symposium on Mosque Architecture: The Historic and Urban Developments of Mosque Architecture (pp. 147169). Riyadh, KSA: King Saud University

11. Utaberta, N., Sojak, S. D. ., Surat, M., Che-Ani, A, I., \& Tahir, M. M. (2012). Typological Study of Traditional Mosque Ornamentation in Malaysia Prospect of Traditional Ornament in Urban Mosque. International Journal of Civil, Architectural Science and Engineering, 6(7), 43-50.

12. Kinuthia, B. (2009). Industrialization in Malaysia: Changing role of Government and Foreign Firms. DEGIT XIV Conference Paper, (March), 1-36. Retrieved from http://degitxiv.cide.edu/PapersDegitXiv/Industrializ ationMalaysiaBethuel.pdf

13. Mohd Rasdi, M. T., \& Utaberta, N. (2007). Mosque Architecture in Malaysia: Jurnal Alam Bina, 9(3), $1-24$.

14. Utaberta, N., Afizi, K., Azimin, K. \&, Mohd, S., \& Abstrak, T. (2009). Tipologi Reka Bentuk Masjid Tradisional di Indonesia. International Journal of the Malay World and Civilisation, 27(2), 229-245.

15. Ahmad, M. F. Bin, Utaberta, N., Mohd Yunos, M. Y., Ismail, N. A., Ismail, S., \& Ariffin, N. F. M. (2015). The Issue of Land Insufficiency for Building Mosques in Urban Context. RESEARCH JOURNAL OF FISHERIES AND HYDROBIOLOGY, 10(October), 100-104. 